\title{
Reduced complement of dopaminergic neurons in the substantia nigra pars compacta of mice with a constitutive "low footprint" genetic knockout of alpha- synuclein
}

Valeria V. Goloborshcheva ${ }^{1,2}$, Kirill D. Chaprov ${ }^{1,2}$, Ekaterina V. Teterina ${ }^{2}$, Ruslan Ovchinnikov ${ }^{2,3}$ and Vladimir L. Buchman ${ }^{1,2^{*}}$

\begin{abstract}
Previous studies of the alpha-synuclein null mutant mice on the C57Bl6 genetic background have revealed reduced number of dopaminergic neurons in their substantia nigra pars compacta (SNpc). However, the presence in genomes of the studied mouse lines of additional genetic modifications that affect expression of genes located in a close proximity to the alpha-synuclein-encoding Snca gene makes these data open to various interpretations. To unambiguously demonstrate that the absence of alpha-synuclein is the primary cause of the observed deficit of dopaminergic neurons, we employed a recently produced constituent alpha-synuclein knockout mouse line B6(Cg)Snca ${ }^{t m 1.2 V l b} / \mathrm{J}$. The only modification introduced to the genome of these mice is a substitution of the first coding exon and adjusted short intronic fragments of the Snca gene by a single loxP site. We compared the number of dopaminergic neurons in the SNpc of this line, previously studied B6(Cg)-Snca ${ }^{\text {tm } / R o s l} / \mathrm{J}$ line and wild type littermate mice. A similar decrease was observed in both knockout lines when compared with wild type mice. In a recently published study we revealed no loss of dopaminergic neurons following conditional inactivation of the Snca gene in neurons of adult mice. Taken together, these results strongly suggest that alpha-synuclein is required for efficient survival or maturation of dopaminergic neurons in the developing SNpc but is dispensable for survival of mature SNpc dopaminergic neurons.
\end{abstract}

Keywords: Dopaminergic neurons, Substantia nigra, Striatum, Alpha-synuclein, Null mutant mice

\footnotetext{
* Correspondence: buchmanvl@cf.ac.uk

${ }^{1}$ School of Biosciences, Cardiff University, Museum Avenue, Cardiff CF10 3AX, UK

${ }^{2}$ Institute of Physiologically Active Compounds Russian Academy of Sciences (IPAC RAS), 1 Severniy proezd, Chernogolovka, Moscow Region, Russian Federation 142432

Full list of author information is available at the end of the article
}

(c) The Author(s). 2020 Open Access This article is licensed under a Creative Commons Attribution 4.0 International License, which permits use, sharing, adaptation, distribution and reproduction in any medium or format, as long as you give appropriate credit to the original author(s) and the source, provide a link to the Creative Commons licence, and indicate if changes were made. The images or other third party material in this article are included in the article's Creative Commons licence, unless indicated otherwise in a credit line to the material. If material is not included in the article's Creative Commons licence and your intended use is not permitted by statutory regulation or exceeds the permitted use, you will need to obtain permission directly from the copyright holder. To view a copy of this licence, visit http://creativecommons.org/licenses/by/4.0/ The Creative Commons Public Domain Dedication waiver (http://creativecommons.org/publicdomain/zero/1.0/) applies to the data made available in this article, unless otherwise stated in a credit line to the data. 


\section{Background}

Gain-of-function of alpha-synuclein has been strongly linked to aetiology and pathogenesis of Parkinson's and several other neurodegenerative diseases (recent advances and perspectives are summarised in Ref [1]). However, despite a growing body of evidence that suggests its involvement in many important molecular processes in healthy neurons, predominantly in presynaptic terminals (for recent review see Ref [2]), it is not clear if alpha-synuclein was required for survival and/or maturation of neurons. Previous studies have demonstrated that at least on the C57Bl6 genetic background, adult mice lacking alpha-synuclein as the result of a naturally occurred mutation or targeted inactivation of the encoded gene have reduced complement of dopaminergic neurons in their SNpc [3-7]. This deficiency becomes already evident in E12.5 embryonic brains and is not progressive $[3,4,7]$. An uncertainty in interpretation of these results is due to a possibility that some additional genetic modifications present in both mouse lines used in these studies, rather than the absent of alphasynuclein per se, could potentially cause partial loss of dopaminergic neurons. A naturally occurred deletion in the genome of Harlan UK C57Bl6 mice spans over approximately 350 kilobases, which causes the loss of function not only of alpha-synuclein encoded Snca, but also of several other genes [8]. Mice of B6(Cg)-Snca ${ }^{\text {tm1Rosl } / J}$ line $[9,10]$ were produced by homologous recombination that resulted in a substitution of Snca exons by a neo expression cassette, which presence dramatically activate neuronal expression of a neighbouring Mmrn1 gene encoding multimerin 1, a protein whose function in the nervous system is enigmatic (Additional file 1). To avoid any disparity in the interpretation of data obtained in different mouse models and reaffirm that the loss of alphasynuclein is the primary cause of the deficit of dopaminergic neurons in the substantia nigra of null mutant mice, we employed a line of mice with a "clean knockout" of alpha-

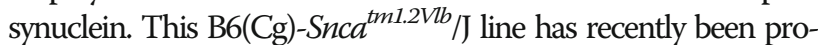
duced in our laboratory by Cre-driven recombination in the genome of "floxed" and neo-free mice of B6(Cg)-Snca tm1.1Vlb $/ \mathrm{J}$ line followed by crosses with C57Bl6 mice to eliminate the CMV-Cre transgenic cassette. Therefore, the only foreign DNA sequence remaining in the genome of $\mathrm{B} 6(\mathrm{Cg})-S n c a^{t m 1.2 \mathrm{Vlb}} / \mathrm{J}$ mice is a single loxP site substituting the first coding exon of Snca gene and some adjusted short intronic sequences. This genetic modification completely abolishes production of alphasynuclein in homozygous animals [11].

\section{Methods}

Null mutant and wild type littermates were produced by intercrossing of heterozygous animals and genotyped as
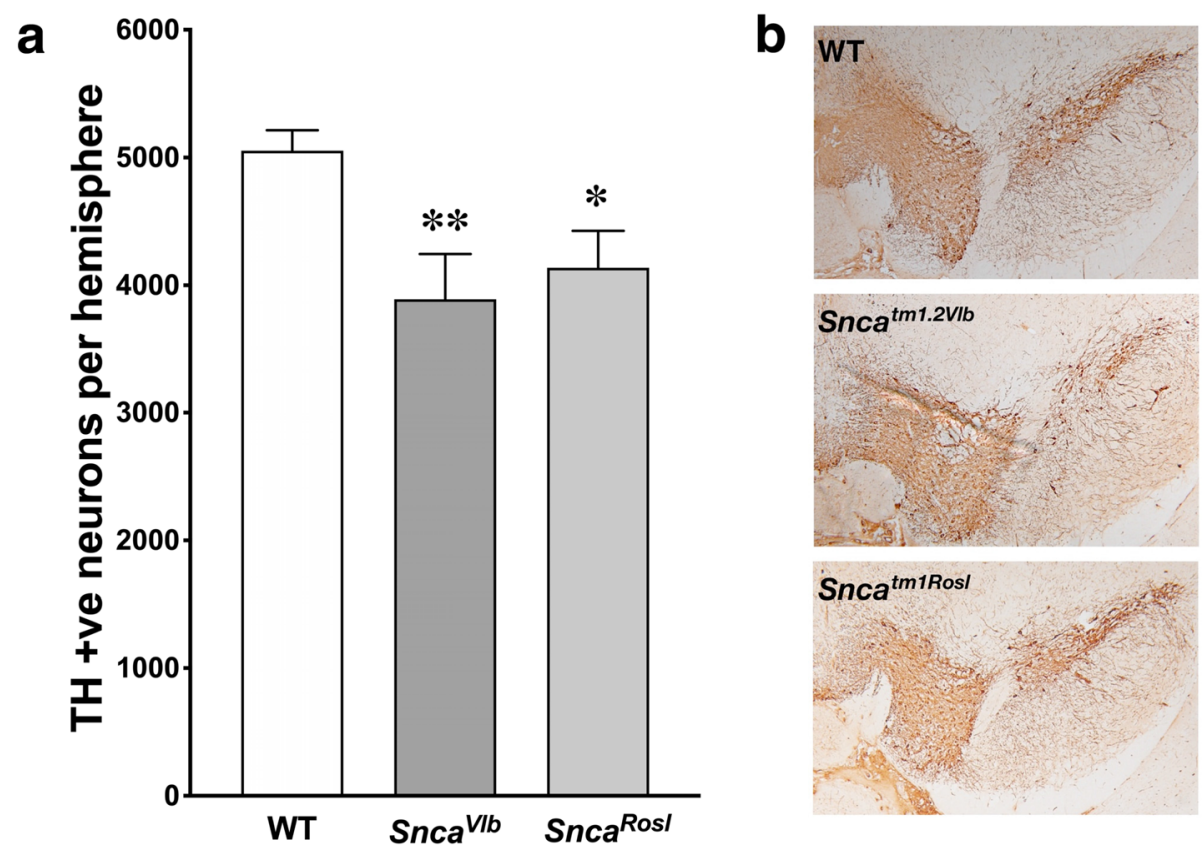

Fig. 1 Similar decrease in the number of dopaminergic neurons in SNpc of two alpha-synuclein knockout lines. a) The number of TH-positive

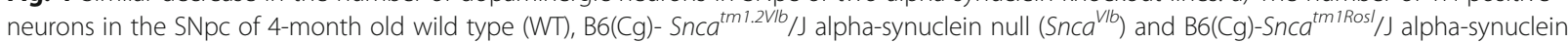
null $\left(S n c a^{\text {Rosl}}\right)$ mice. Bar charts show mean \pm SEM of numbers of stereologically counted neurons in SNpc of 8 animals for each genotype. Statistical analysis using one-way ANOVA with Dunnett's multiple comparisons test revealed significant difference between WT and each of null mutant mouse groups ( $\left.F(2,45)=4.854 ; p=0.0123 ;{ }^{* *} p=0.0094 ;{ }^{*} p=0.0451\right)$, whereas the difference between two null mutant mouse groups was not significant $(p=0.5329)$. b) Representative images of brain sections through SNpc region immunostained with antibody against TH 
described elsewhere $[9,10]$. Brains of 4-month old male mice we fixed, histological sections prepared and immunostained with antibody against tyrosine hydroxylase ( $\mathrm{TH}$, mouse monoclonal antibody, clone TH-2, Sigma diluted 1:1000); TH-positive neurons in the SNpc were stereologically counted as described previously $[3,4,6]$.

\section{Results and discussion}

Our morphometric analysis revealed that the total number of dopaminergic neurons in the $\mathrm{SNpc}$ of adult B6(Cg)-Snca ${ }^{\text {tm1Rosl }} / \mathrm{J}$ mice was $18 \pm 5.7 \%$ lower than in the SNpc of wild type mice (Fig. 1, an additional Excel file, Additional file 2, shows raw count data). This is consistent with the previously reported data for this line as well as for Harlan UK C57Bl6 alpha-synuclein null mutant line [3-6]. Importantly, a similar reduction $(23 \pm 7.0 \%)$ was found in the $\mathrm{SNpc}$ of a new "clean knockout" B6(Cg)-Sncat $a^{\text {tm } 1.2 V l b} / \mathrm{J}$ line (Fig. 1). The latter result clearly implies that dopaminergic neuron deficit observed in studied alpha-synuclein null mutant mouse lines is indeed caused by the lack of alpha-synuclein.

In another recent study we have demonstrated that inactivation of Snca gene by the same genetic modification as in $\mathrm{B} 6(\mathrm{Cg})-\mathrm{Snca}^{t m 1.2 V l b} / \mathrm{J}$ line but induced by Cre recombination in neurons of adult or ageing $\mathrm{B} 6(\mathrm{Cg})$ $S n c a^{t m 1.1 \mathrm{Vlb}} / \mathrm{J}$ animals, caused complete depletion of alpha-synuclein from the dorsal striatum, a brain region where presynaptic terminals (i.e. sites of the predominant localisation of this protein) of the $\mathrm{SNpc}$ dopaminergic neurons are located. However, such a late-onset depletion did not lead to any loss of SNpc dopaminergic neurons [12]. Taken together, results of our two studies strongly suggest that alpha-synuclein is required for efficient survival or maturation of dopaminergic neurons in the developing SNpc but is dispensable for survival of mature SNpc dopaminergic neurons. It is also cannot be currently excluded that a certain population of developing dopaminergic neurons is particularly sensitive to the absence of alpha-synuclein.

\section{Supplementary information}

Supplementary information accompanies this paper at https://doi.org/10. 1186/s13041-020-00613-5.

Additional file 1 Expression levels of Mmrn 1 mRNA in the cerebral cortex of wild type and synuclein null mutant mice. Bar chart shows relatives level of Mmrn 1 mRNA in the cerebral cortex of the wild type (WT), B6(Cg)-Snca ${ }^{t m 1.2 V / b} / J$ alpha-synuclein null $\left(S_{n c a^{V / b}}\right)$ and B6(Cg)Snca ${ }^{\text {tmiRosl} / J ~ a l p h a-s y n u c l e i n ~ n u l l ~(S n c a ~}{ }^{\text {Rosl }}$ ) mice estimated by real-time quantitative RT-PCR.

Additional file 2. Number of TH-positive neurons in SNpc of wild type and synuclein null mutant mice. Raw data for neurons number counts in the left and right SNpc of individual animals used in the study.

\section{Abbreviations}

SNpc: Substantia nigra pars compacta; TH: Tyrosine hydroxylase

\section{Acknowledgements}

Not applicable.

\section{Authors' contributions}

VLB conceived and supervised the study and was a major contributor in writing the manuscript. WG prepared/stained histological sections and counted neurons. KDC collected tissues and counted neurons. EVT prepared cohorts and genotyped experimental animals, collected tissues. RO collected tissues, prepared/stained histological sections. All authors were involved in data analysis and manuscript preparation. All authors read and approved the final manuscript.

\section{Funding}

This work was supported by grants from The Michael J. Fox Foundation for Parkinson's Research (Rapid Response Innovation Award 2013 and Research Grant 8116.01), Parkinson's UK (Project Grant G-1006) and Russian Science Foundation (Grant 19-14-00064).

Availability of data and materials

All data generated or analysed during this study are included in this published article [in its supplementary information file].

Ethics approval and consent to participate

All animal work was carried out in accordance with the United Kingdom (Scientific Procedures) Act (1986) and European Directive EC 86/609, and has been approved by the Cardiff University Ethical Review Committee and the Home Office (Project Licences 30/2844 and 30/3412).

Consent for publication

Not applicable.

\section{Competing interests}

The authors declare that they have no competing interests.

\section{Author details}

${ }^{1}$ School of Biosciences, Cardiff University, Museum Avenue, Cardiff CF10 3AX, UK. Institute of Physiologically Active Compounds Russian Academy of Sciences (IPAC RAS), 1 Severniy proezd, Chernogolovka, Moscow Region, Russian Federation 142432. ${ }^{3}$ Pirogov Russian National Research Medical University, Ostrovitianov Str., 1, Moscow, Russian Federation 117997.

Received: 27 March 2020 Accepted: 28 April 2020

Published online: 11 May 2020

\section{References}

1. Bras IC, Dominguez-Meijide A, Gerhardt E, Koss D, Lazaro DF, Santos PI, Vasili E, Xylaki M, Outeiro TF. Synucleinopathies: where we are and where we need to go. J Neurochem. 2020. https://doi.org/10.1111/jnc.14965.

2. Sulzer D, Edwards $\mathrm{RH}$. The physiological role of alpha-synuclein and its relationship to Parkinson's disease. J Neurochem. 2019;150:475-86.

3. Al-Wandi A, Ninkina N, Millership S, Williamson SJ, Jones PA, Buchman VL. Absence of alpha-synuclein affects dopamine metabolism and synaptic markers in the striatum of aging mice. Neurobiol Aging. 2010;31:796-804.

4. Connor-Robson N, Peters OM, Millership S, Ninkina N, Buchman VL. Combinational losses of synucleins reveal their differential requirements for compensating age-dependent alterations in motor behavior and dopamine metabolism. Neurobiol Aging. 2016;46:107-12.

5. Garcia-Reitboeck P, Anichtchik O, Dalley JW, Ninkina N, Tofaris GK, Buchman VL, Spillantini MG. Endogenous alpha-synuclein influences the number of dopaminergic neurons in mouse substantia nigra. Exp Neurol. 2013;248: 541-5.

6. Robertson DC, Schmidt O, Ninkina N, Jones PA, Sharkey J, Buchman VL. Developmental loss and resistance to MPTP toxicity of dopaminergic neurones in substantia nigra pars compacta of gamma-synuclein, alphasynuclein and double alpha/gamma-synuclein null mutant mice. J Neurochem. 2004:89:1126-36.

7. Tarasova TV, Lytkina OA, Goloborshcheva W, Skuratovskaya LN, Antohin Al, Ovchinnikov RK, Kukharsky MS. Genetic inactivation of alphasynuclein affects embryonic development of dopaminergic neurons of the substantia nigra, but not the ventral tegmental area, in mouse brain. PeerJ. 2018;6:e4779. 
8. Specht CG, Schoepfer R. Deletion of the alpha-synuclein locus in a subpopulation of C57BL/6J inbred mice. BMC Neurosci. 2001;2:11.

9. Abeliovich A, Schmitz Y, Farinas I, Choi-Lundberg D, Ho WH, Castillo PE, Shinsky N, Verdugo JM, Armanini M, Ryan A, et al. Mice lacking alphasynuclein display functional deficits in the nigrostriatal dopamine system. Neuron. 2000;25:239-52.

10. Ninkina N, Papachroni K, Robertson DC, Schmidt O, Delaney L, O'Neill F, Court F, Rosenthal A, Fleetwood-Walker SM, Davies AM, Buchman VL. Neurons expressing the highest levels of gamma-synuclein are unaffected by targeted inactivation of the gene. Mol Cell Biol. 2003;23:8233-45.

11. Ninkina N, Connor-Robson N, Ustyugov AA, Tarasova TV, Shelkovnikova TA Buchman VL. A novel resource for studying function and dysfunction of alpha-synuclein: mouse lines for modulation of endogenous Snca gene expression. Sci Rep. 2015;5:16615.

12. Ninkina N, Tarasova TV, Chaprov KD, Roman AY, Kukharsky MS, Kolik LG, Ovchinnikov R, Ustyugov AA, Durnev AD, Buchman VL. Alterations in the nigrostriatal system following conditional inactivation of a-synuclein in neurons of adult and aging mice. Neurobiol Aging. 2020. https://doi.org/10. 1016/..neurobiolaging.2020.02.026.

\section{Publisher's Note}

Springer Nature remains neutral with regard to jurisdictional claims in published maps and institutional affiliations.

Ready to submit your research? Choose BMC and benefit from:

- fast, convenient online submission

- thorough peer review by experienced researchers in your field

- rapid publication on acceptance

- support for research data, including large and complex data types

- gold Open Access which fosters wider collaboration and increased citations

- maximum visibility for your research: over $100 \mathrm{M}$ website views per year

At $\mathrm{BMC}$, research is always in progress.

Learn more biomedcentral.com/submissions 